\title{
PADRÃO DE ESPECIALIZAÇÃO DO COMÉRCIO INTERNACIONAL DE MATO GROSSO (1999-2014)
}

Specialization Pattern Of International Trade In Mato Grosso (1999-2014)

Rodrigo Abbade da Silva ${ }^{1}$
Daniel Arruda Coronel
Mygre Lopes da Silva $^{3}$

Resumo: Este trabalho buscou analisar o padrão de especialização do comércio internacional do estado de Mato Grosso, identificando os setores produtivos mais dinâmicos, no período entre 1999 e 2014. Neste sentido, calcularam-se os indicadores de Vantagem Comparativa Revelada Simétrica (IVCRS), de Comércio Intraindústria (CII), de Concentração Setorial das Exportações (ICS) e Taxa de Cobertura das Importações (TC) com os dados obtidos da Secretaria de Comércio Exterior - SECEX. Os resultados indicaram que, apesar do estado ter como objetivo esforçar-se para a diversificação do setor produtivo e, assim, da pauta exportadora, esta continua a ser predominantemente composta por setores baseados em recursos naturais. Com isso, é possível constatar que os setores especializados no comércio internacional são aqueles que apresentam vantagens comparativas convencionais.

Palavras-chave: Exportações. Vantagem comparativa. Mato Grosso.

\section{SPECIALIZATION PATTERN OF INTERNATIONAL TRADE IN MATO GROSSO (1999-2014)}

Abstract: This study aims to analyze the pattern of specialization of international trade in the state of Mato Grosso, identifying the most dynamic productive sectors between 1999 and 2014. In this sense, the Revealed Comparative Advantage Symmetric indices (IVCRS) was calculated, as well as the Intra-Industry Trade indicator (CII), the Industry Concentration of Exports (ICS) indicator and the Imports Coverage Rate (CT) based on data obtained from the Bureau of Foreign Trade - SECEX. The results indicated that despite the fact that the state aims to strive for diversification of the productive sector and thus the export portfolio, it continues to be predominantly composed of sectors based on natural resources. Accordingly, it is noteworthy that the sectors specialized in international trade are those with conventional comparative advantages.

Keywords: Exports; Comparative advantage; Mato Grosso.

\footnotetext{
${ }^{1}$ Mestrando em Administração pela Universidade Federal de Santa Maria (UFSM) abbaders@gmail.com

2 Doutor em Economia Plicada pela Universidade Federal de Viçosa (UFV). Professor Adjunto do departamento de Ciências Administrativas da Universidade Federal de Viçosa. daniel.coronel@uol.com.br

3 Mestranda em Administração pela Universidade Federal de Santa Maria (UFSM) mygrelopes@gmail.com
} 
Classificação JEL: F02, F05.

\section{INTRODUÇÃO}

A abertura comercial e a estabilização macroeconômica consolidadas, em meados, da década de 1990, mudaram os rumos da economia brasileira. A falta de competitividade de alguns setores nacionais observada após a abertura comercial fez com que a indústria passasse por um choque de competitividade devido ao aumento da exposição aos competidores externos.

A abertura comercial ocorreu porque as capacidades produtivas das nações são diferentes e é compensatório abrir mão de produzir tudo que o país necessita para então produzir produtos que possuem vantagem comparativa e comercializá-los com outros países, obtendo então os ganhos de comércio (KRUGMAN; OBSTFELD, 2010). A troca voluntária entre nações é defendida desde a teoria seminal de comércio internacional de David Ricardo, que se apoiava no argumento das vantagens comparativas.

Neste cenário, houve o processo de redução das tarifas sobre o comércio internacional no país, o qual contribuiu para o aumento da quantidade de produtos comercializados com o resto do mundo. E, nesse contexto, o estado brasileiro de Mato Grosso - MT que, em 1999, respondia por aproximadamente $1,6 \%$ da pauta exportações Brasil, chegou a 6,7\% em 2014 (SECEX, 2015).

Com a evolução das teorias para explicar o comércio internacional, surgiu o conceito de comércio intraindústria. Esse conceito reflete a complexidade produtiva e os padrões de comércio internacional no mundo moderno, complexidade essa não capturada pelos modelos teóricos anteriores. Essa modalidade de comércio traz consigo maiores ganhos e incentivos ao comércio internacional do que os descritos anteriormente, principalmente pela diferenciação de produtos e concorrência imperfeita (KRUGMAN; OBSTFELD, 2010). Desta forma, como algumas alterações econômicas no Brasil refletem em seus estados, faz-se relevante responder à seguinte questão: qual o padrão de especialização das exportações do estado brasileiro de Mato Grosso, após a abertura econômica do país?

Neste contexto, este trabalho tem como objetivo geral analisar o padrão de especialização das exportações de Mato Grosso, no período 1999 a 2014, cujo marco inicial representa o ano em que o Brasil adotou o regime de câmbio flutuante (VIANNA; BRUNO; MODENESI, 2010), e, especificamente, analisar os setores produtivos mais dinâmicos do estado, bem como compreender a composição da pauta exportadora mato-grossense, analisando as mudanças na inserção externa do estado. Para alcançar os objetivos, serão utilizados quatro indicadores de comércio internacional, a saber: indicador de Vantagem Comparativa Revelada Simétrica (IVCRS), Comércio Intraindústria (CII), Concentração Setorial das Exportações (ICS) e Taxa de Cobertura das Importações (TC).

Além desta introdução, o artigo está organizado da seguinte forma: a seção dois apresenta o referencial teórico; na seção três, é apresentada a metodologia; na seção quatro, tem-se a análise e discussão dos resultados; e, por fim, é apresentada a conclusão. 


\section{RERENCIAL TEÓRICO}

Nesta seção, apresenta-se o marco teórico utilizado na análise do padrão de especialização do comércio internacional de Mato Grosso, realçando-se diversos elementos citados na literatura econômica internacional que possam ser úteis para a sustentação da análise empírica. Desta forma, procura-se revisar a evolução dos conceitos de políticas comerciais dentro das teorias sobre comércio internacional e também a teoria das vantagens comparativas e seus desdobramentos ao longo do tempo.

Adam Smith e David Ricardo foram os precursores das abordagens teóricas sobre os benefícios do comércio entre nações. Smith (2009), em 1776, defende que o livre comércio é a melhor política para a economia de uma nação e suas análises estão concentradas no teorema das vantagens absolutas, no qual sustenta que cada país deve se especializar na produção do bem no qual consiga produzir com menores custos de produção que outros países, medidos em horas de trabalho. Além disso, a especialização implica aumento da produção global dos bens, o que permite o aumento do consumo em pelo menos um dos países, gerando o que se denomina benefícios ou ganhos do comércio. Portanto, o objetivo do comércio seria aumentar 0 consumo.

Todavia, Ricardo (1817) sustentou e complementou o modelo de Smith, mostrando que os países comercializam mesmo que não possuam vantagem absoluta em nenhum bem, basta que o país tenha vantagens comparativas. Segundo, Krugman e Obstfeld (2010), de acordo com o princípio desta teoria, os países tenderiam a exportar produtos em que possuem menor custo de oportunidade e importar o que possuem maior custo de oportunidade, relativo a outros países, os quais são determinados pela produtividade do trabalho.

Heckscher e Ohlin (1991), em 1933, refinaram a teoria das vantagens comparativas, pois perceberam que o custo de oportunidade pode ser associado a diversos fatores, não apenas relacionados ao fator trabalho como na teoria de Smith e Ricardo. Além disso, para Heckscher e Ohlin, as diferenças nas dotações relativas aos fatores de produção justificam a existência de comércio, principal e geralmente os fatores terra (especializa-se na agropecuária, setor primário), capital (especializa-se na produção industrial, setor secundário) e trabalho (especializa-se em serviços, setor terciário). De acordo com Krugman e Obstfeld (2010), o modelo demonstra que a especialização de cada país no comércio internacional é influenciada pela interação do fator de produção abundante e a sua intensidade relativa de produção. Ainda nesta perspectiva, Heckscher e Ohlin (1991) destacam que os proprietários dos fatores abundantes são os favorecidos nas relações, e os proprietários dos fatores escassos perdem com o comércio. Tal modelo encontrou suporte em análises das pautas de trocas entre países industrializados e não industrializados, levando a crer que sua validade poderia ser estendida a quaisquer outras situações.

No entanto, diversos estudos empíricos contestaram a assertiva de Heckscher e Ohlin. A mais conhecida evidência em contrário foi o estudo do economista russo Wassily Leontief, com base na balança comercial norteamericana até 1947, que indicava um déficit em produtos industrializados, embora os EUA fossem o país com maior concentração do fator capital per capita dessa época, em relação aos principais parceiros comerciais. Desta 
forma, o estudo ficou conhecido como Paradoxo de Leontief e conduziu diversos pensadores em direção a novas tentativas de compreender o que realmente determina os fluxos comerciais mundiais (FAUSTINO, 1992).

Em virtude desses estudos, foram realizadas modificações no modelo original de Heckscher e Ohlin. No entanto, a teoria não conseguia explicar duas características importantes da economia internacional: o comércio entre países com fatores semelhantes e as empresas transnacionais. Nesse sentido, Linder (1961), Krugman e Obstfeld (2010) destacaram-se na busca por explicações complementares, incorporando nos modelos características de mercados imperfeitos para explicar o comércio intraindustrial, caracterizado por troca de produtos semelhantes, mas não homogêneos, os quais estão baseados em economia de escala e diferenciação de produtos. Somam-se a estas duas variáveis as barreiras de comércio, as diferenças de preferências e de tecnologias entre nações.

Nessa expectativa, a teoria do comércio internacional avançou em suas análises e foram desenvolvidos indicadores para explicar as modificações na atuação internacional dos países. Balassa (1965) desenvolveu estudos de competitividade no comércio internacional, criando o conceito de vantagem comparativa revelada (VCR), no qual os preços pós-comércio determinam a vantagem comparativa. Este é outro tipo de explicação para identificar setores nos quais um país possui vantagens competitivas determinadas pelos custos relativos de produção e, por conseguinte, pode obter vantagens comparativas na exportação. Esse método tem como pressuposto o comércio livre. No entanto, Figueiredo e Santos (2005) destacam que, por mais que haja limitações na análise do indicador VCR, este é amplamente utilizado pela facilidade de cálculo e pela capacidade de acompanhar o desempenho do fluxo comercial externo, o que permite avaliar os impactos de políticas de estímulo às exportações. Ademais, permite identificar o padrão de especialização internacional que segue a pauta de exportação dos países, porém não permite avaliar se esses padrões são ótimos ou não. Em outros termos, pode demonstrar as tendências da especialização internacional de uma economia, definindo a competitividade de determinado produto (FAJNZYLBER, P.; SARTI, F.; LEAL, 1993).

Devido à inadequação das teorias anteriores para explicar o comércio internacional, pelo fato de considerarem a ausência de economias de escala, as tecnologias constantes, a imobilidade dos fatores e a concorrência perfeita entre os agentes, a teoria da vantagem competitiva de Michael Porter traz um conceito mais condizente com a realidade moderna. A vantagem competitiva assenta-se na produtividade, por meio de economias de escala, diferenciação de produto, mudanças tecnológicas. Desta forma, o comércio internacional permite 0 aumento de produtividade e elimina a necessidade da produção de todos os bens e serviços dentro de um país. A questão mais relevante é como as empresas e os países melhoram a qualidade dos fatores, aumentam a produtividade com que são utilizados e criam novos (PORTER, 1989). Cabe ressaltar que a teoria de Porter se baseia em estudos empíricos em nações industrializadas, consiste nos países desenvolvidos, os quais necessitam cada vez mais de aprimoramento do produto no aspecto qualitativo, que é o mais importante e não no quantitativo. 
O presente estudo apoia-se nas assertivas da teoria de Heckscher e Ohlin, que, mesmo com as suas limitações, é capaz de identificar quais são os principais fatores produtivos e vantagens comparativas.

\subsection{Barreiras ao comércio}

Um dos grandes obstáculos ao livre comércio, que tem suscitado várias discussões, novas teorias e novos modelos de comércio internacional são as barreiras comerciais que as nações aplicam com o objetivo de proteger seus mercados. As barreiras comerciais são uma distorção ao livre comércio e à circulação de mercadorias. Há diversas formas de protecionismo, entre elas a tarifa, um imposto cobrado quando um bem é importado (KRUGMAN; OBSTFELD, 2010).

As tarifas podem ser de três tipos: ad valorem, específicas e compostas. De acordo com Salvatore (2000), as tarifas ad valorem são expressas como uma porcentagem fixa do valor da commodity comercializada. As tarifas específicas são expressas com uma quantia fixa por unidade física da commodity comercializada. A tarifa composta é uma combinação das tarifas ad valorem e específica. As tarifas eram a forma mais utilizada para um país proteger a economia e seus efeitos eram distintos, pois os produtores se beneficiavam, no entanto, os consumidores eram prejudicados, visto que pagavam um preço mais elevado pelas mercadorias (BRUM, A. L.; HECK, 2005).

As tarifas diminuíram nos últimos tempos, pois os governos preferem proteger suas indústrias por meio de barreiras não tarifárias, como forma de evitar sanções e discussões na Organização Mundial do Comércio importado (KRUGMAN; OBSTFELD, 2010). A proteção com base nas barreiras não tarifárias passou a se chamar de o "novo protecionismo", em contraste com o velho protecionismo, que se baseava nas tarifas alfandegárias (WILLIAMSON; MILNER; WHEATSHEAF, 1991).

As principais barreiras não tarifárias utilizadas pelos países são cotas, restrição voluntária às exportações, subsídio às exportações e as novas barreiras comerciais, que são técnicas, ecológicas, burocráticas e sanitárias (AZÚA, 1986 e MAIA, 2006). A cota é uma restrição quantitativa que limita as importações de determinados bens. Define-se restrição voluntária às exportações como um pedido do país importador ao país exportador, no sentido de reduzir a quantidade de mercadorias exportadas, a fim de evitar maiores sanções no âmbito macroeconômico internacional (KRUGMAN; OBSTFELD, 2010).

Os subsídios às exportações são pagamentos diretos, concessão de isenção fiscal, empréstimos subsidiados aos exportadores da nação. Os subsídios também podem ocorrer na forma de empréstimos a juros baixos concedidos a compradores estrangeiros de maneira a estimular as exportações do país (SALVATORE, 2000). As barreiras técnicas são mecanismos que as nações utilizam para proteger seu mercado, ou seja, a nação só importará determinados produtos se seguirem certos padrões. As barreiras ecológicas têm como pretexto proteger a natureza. Entende-se por barreiras sanitárias a proibição da importação de determinadas mercadorias por considerar-se que esses produtos podem causar problemas à saúde da população. Estas 
barreiras podem ser vistas como uma forma das nações protegerem seus mercados (MAIA, 2006).

\section{METODOLOGIA}

Nesta seção, são apresentados os quatro indicadores utilizados no presente estudo, os quais têm por objetivo identificar os produtos do estado de Mato Grosso com vantagens comparativas no comércio exterior.

O primeiro deles consiste no indicador de Vantagem Comparativa Revelada Simétrica (IVCRS), formalmente definido pela Equação (1). De acordo com Hidalgo (1998), este indicador revela a relação entre participação de mercado do setor e a participação da região (estado) no total das exportações do país, fornecendo uma medida da estrutura relativa das exportações de uma região (estado). O IVCRS varia de forma linear entre -1 e 1. O país que tiver resultado entre 0 e 1 terá vantagem comparativa no produto analisado. Se o IVCRS for igual a zero, terá a competitividade média dos demais exportadores e, se variar entre -1 e 0 , terá desvantagem comparativa (LAURSEN, 1998).

$$
\operatorname{IVCRS~}_{i k}=\left(\frac{\mathrm{x}_{i j} / \mathrm{x}_{i z}}{\mathrm{x}_{j} / \mathrm{x}_{z}}-1\right) /\left(\frac{\mathrm{x}_{i j} / \mathrm{x}_{i z}}{\mathrm{x}_{j} / \mathrm{x}_{z}}+1\right)
$$

em que:

$\mathrm{X}_{i j}$ representa valor das exportações do setor i pelo Estado j (MT);

$\mathrm{X}_{i z}$ representa o valor das exportações do setor i da zona de referência $z$ (Brasil);

Xj representa valor total das exportações do estado j (MT); e, (Brasil).

$\mathrm{X}_{\mathrm{z}}$ representa valor total das exportações da zona de referência $\mathrm{z}$

Ainda, conforme Hidalgo (1998), quando uma região exporta um grande volume de um determinado produto em relação ao que é exportado desse mesmo produto pelo país, ela possui vantagem comparativa na produção desse bem. Além disso, em um ambiente cada vez mais globalizado e integrado, o fluxo comercial é caracterizado por um crescente comércio intraindústria. A expansão do comércio nos processos de integração econômica, em geral, acontece através desse tipo de comércio. Assim, o conhecimento desse comércio é importante na formulação de estratégias de inserção internacional para uma economia (HIDALGO; DA MATA, 2004).

O segundo é o Índice de Comércio Intraindústria (CII), o qual visa caracterizar o comércio do estado de Mato Grosso. Este índice consiste na utilização da exportação e importação simultânea de produtos do mesmo setor. Com o avanço e difusão dos processos tecnológicos entre os países, muda-se a configuração do comércio internacional e o peso das vantagens comparativas (abundância de recursos). Apresenta-se como destaque o crescimento do comércio interindustrial. Conforme Appleyard et al. (2010), diferentemente do comércio interindustrial, o comércio intraindústria é explicado pelas economias de escala e pela diferenciação do produto.

O indicador setorial do comércio intraindustrial (CII) foi desenvolvido por Grubel e Lloyd (1975) e pode ser apresentado conforme a Equação 2: 


$$
C I I=1-\frac{\sum_{i}\left|X_{i}-M_{i}\right|}{\sum_{i}\left(X_{i}+M_{i}\right)}
$$

em que:

$\mathrm{X}_{\mathrm{i}}$ representa as exportações do produto $\mathrm{i}$;

$\mathrm{M}_{\mathrm{i}}$ representa as importações do produto i.

Quando o indicador Cll se aproximar de zero, pode-se concluir que há comércio interindustrial, neste caso, o comércio é explicado pelas vantagens comparativas, ou seja, observa-se a presença de comércio entre produtos de diferentes setores do Mato Grosso com os países parceiros. Esse evento pode ser observado ao constatar ocorrência de apenas importação ou apenas exportação do setor i (ou produto i). Por outro lado, quando Cll for maior que 0,5 (Cll>0,5), o comércio é caracterizado como sendo intraindustrial.

Assim, o padrão de comércio intraindustrial reflete uma pauta exportadora que, por sua vez, sucede uma estrutura produtiva dinamizada em progresso tecnológico e em economias de escala (ampliação de mercados). Todavia, a configuração interindustrial reflete o ordenamento entre os setores produtivos, baseado no uso da dotação de fatores e sob concorrência perfeita. Esse arranjo explicativo das trocas comerciais pode indicar se determinado participante do comércio internacional alcançou ganhos de competitividade. Ressalta-se que, em meio à profusão de conceitos que foram dados a esse termo, entende-se, neste artigo, diante dos alcances e das limitações dos índices utilizados, que alcançar competitividade internacional significa, conforme Ilha, Dornelles, Wegner (2009), atingir os maiores níveis de vantagem comparativa revelada e o padrão de inserção intraindustrial.

O terceiro indicador é o índice de Concentração Setorial das Exportações (ICS), também conhecido como coeficiente Gini-Hirchman, o qual quantifica a concentração das exportações de cada setor exportador i realizados pelo estado j (Mato Grosso). O ICS é representado através da Equação 3:

$$
\operatorname{ICS}_{i j}=\sqrt{\sum_{i}\left(\frac{X_{i j}}{X_{j}}\right)^{2}}
$$

em que:

$\mathrm{X}_{\mathrm{ij}}$ representa as exportações do setor i pelo estado j (MT); e,

$\mathrm{X}_{\mathrm{j}}$ representa as exportações totais do estado $\mathrm{j}(\mathrm{MT})$.

O ICS varia entre 0 e 1 , e, quanto mais próximo de 1 , mais concentradas serão as exportações em poucos setores e, por outro lado, quanto mais próximo de 0 , mais diversificada será a composição da pauta de exportações. Pinheres e Ferratino (1997) apresentam abordagem alternativa para o cálculo das concentrações.

O quarto indicador é a taxa de cobertura das importações (TC), o qual indica quantas vezes o volume das exportações do setor i está cobrindo seu volume de importação. O índice é obtido através da Equação 4:

$$
T C_{i j}=\frac{X_{i j} / M_{i j}}{X_{i} / M_{i}}
$$

em que: 
Xij representa as exportações do setor i do Estado j (MT);

$M_{i j}$ representa as importações do setor i do Estado j (MT);

$X_{i}$ representa as exportações do produto i; e,

$\mathrm{M}_{\mathrm{i}}$ representa as importações do produto $\mathrm{i}$.

Segundo Fontenele et. al. (2000), quando $\mathrm{TC}_{\mathrm{ij}}$ é superior à unidade $\left(\mathrm{TC}_{\mathrm{ij}}>1\right)$, identifica-se uma vantagem comparativa em termos de cobertura das exportações, ou seja, as exportações do setor i do estado teriam uma dimensão maior se comparadas às importações do mesmo setor.

Para alcançar o objetivo de explanar o padrão comercial de Mato Grosso no período 1999-2014 e apresentar os setores produtivos do estado que apresentam maior especialização e competitividade, serão utilizados indicadores baseados nos fluxos comerciais. O banco de dados para o cálculo destes indicadores é obtido junto à Secretaria do Comércio Exterior (SECEX) do Ministério do Desenvolvimento, Indústria e Comércio do Brasil (MDIC), que é acessível através do Sistema de Análise de Informações do Comércio Exterior (Aliceweb2) ${ }^{4}$.

Os dados relativos às importações e exportações desagregadas por setores segue o padrão da literatura empírica da área, como apresentam Feistel (2008) e Maia (2005). Os capítulos referem-se aos setores produtivos e, a partir de cada capítulo correspondente ao agrupamento de produtos, obtêmse os valores das importações e exportações ${ }^{5}$.

\section{ANÁLISE E DISCUSSÃO DOS RESULTADOS}

\subsection{Estrutura do comércio exterior de Mato Grosso}

De 1999 a 2014, as exportações totais de Mato Grosso cresceram $1896,7 \%$, as do Brasil $367,3 \%$, e, por outro lado, as importações matogrossenses cresceram 1081,3\%, contra $364,6 \%$ do Brasil. Ou seja, as exportações e importações mato-grossenses cresceram mais que as exportações e importações brasileiras.

De acordo com Santos (2012), o Mato Grosso apresenta produção e exportações predominantemente agrícolas, fruto de políticas aplicadas pelo governo brasileiro. Exemplos disso são a "Marcha para o oeste", implementada em 1930, durante o governo de Getúlio Vargas, e a partir de 1970, a política agropecuária para exportação em Mato Grosso, que o integrou à Amazônia Legal em 1972, implantada pelo governo militar. Os Programas como POLOAMAZÔNIA e POLO-CENTRO, o II Plano de Nacional de Desenvolvimento - PND de 1975 a 1979 e os planos de polos desenvolveram consideravelmente a agropecuária e propiciaram a migração de trabalhadores para a região e a formação da fronteira agrícola mecanizada. Ainda conforme Santos (2012), as áreas urbanas em Mato Grosso, num primeiro momento, tiveram sua origem e formação proporcionadas pela atividade garimpeira e agropecuária e o processo de urbanização nestas áreas se estabeleceu de forma espontânea, isto é, sem um planejamento urbanístico e local do poder

\footnotetext{
${ }^{4}$ O Sistema Aliceweb2 está disponível no site http://aliceweb2.mdic.gov.br.

${ }^{5}$ Para classificar as mercadorias, em 1996, o Brasil passou a utilizar a Nomenclatura Comum do Mercosul (NCM), a qual é utilizada pelos outros integrantes do bloco, baseado no Sistema Harmonizado de Designação e Codificação de Mercadorias (Capítulos SH) - (SECEX, 2015).
} 
público. Também as áreas urbanas criadas a partir do processo de colonização tiveram um planejamento governamental com infraestrutura urbana de serviços de saúde, de educação formal e de apoio para a atividade comercial e de indústrias de transformação (madeireiras e agroindústrias). Além disso, os incentivos a instalações de indústria no estado são incipientes, iniciados na década de 1990, na forma de isenções de imposto sobre Produtos Industrializados - IPI e Imposto Sobre Circulação de Mercadorias - ICMS.

De acordo com a Tabela 1, percebe-se que as exportações e as importações mato-grossenses, em 1999, concentravam-se mais em produtos básicos $(75,5 \%)$ e semimanufaturados (14,1\%). Em 2014, essa ordem foi mantida, porém, constata-se que, ao longo do período, ocorreu um aumento das exportações de produtos básicos, que passou a representar $95,2 \%$, em detrimento das exportações de produtos semimanufaturados, que passou a representar 4,0\%, com mais intensamente em detrimento de produtos manufaturados. Essa relação ocorre de forma complementar para as importações mato-grossenses, ou seja, isso pode indicar que esteja ocorrendo um processo de especialização em commodities e matéria-prima em Mato Grosso.

Tabela 1 - Exportações (X) e Importações (M) segundo fator agregado (em milhões US\$ FOB) - Mato Grosso

\begin{tabular}{|c|c|c|c|c|c|c|c|c|}
\hline \multirow[b]{3}{*}{ Ano } & \multirow{2}{*}{\multicolumn{2}{|c|}{ Básicos }} & \multicolumn{4}{|c|}{ Industrializados $(A+B)$} & & \\
\hline & & & \multicolumn{2}{|c|}{ Semimanufaturados (A) } & \multicolumn{2}{|c|}{ Manufaturados (B) } & \multicolumn{2}{|c|}{ TOT A L } \\
\hline & $x$ & $M$ & $x$ & $\mathrm{M}$ & $x$ & $M$ & $x$ & $\mathrm{M}$ \\
\hline 1999 & 559,6 & 9,7 & 104,7 & 4,8 & 76,7 & 135,1 & 741,0 & 149,7 \\
\hline 2000 & 871,0 & 2,1 & 93,5 & 20,9 & 67,4 & 67,7 & 1031,9 & 90,6 \\
\hline 2001 & 1222,9 & 3,8 & 95,2 & 34,0 & 77,4 & 98,7 & 1395,6 & 136,5 \\
\hline 2002 & 1535,7 & 53,7 & 171,2 & 68,2 & 88,4 & 87,2 & 1795,4 & 209,0 \\
\hline 2003 & 1817,3 & 62,1 & 264,9 & 72,1 & 103,9 & 142,6 & 2186,2 & 276,7 \\
\hline 2004 & 2561,6 & 24,4 & 381,8 & 154,3 & 158,5 & 238,9 & 3101,9 & 417,7 \\
\hline 2005 & 3477,8 & 22,2 & 495,2 & 182,3 & 178,7 & 205,7 & 4151,6 & 410,2 \\
\hline 2006 & 3710,3 & 19,4 & 367,4 & 165,8 & 255,8 & 221,4 & 4333,5 & 406,5 \\
\hline 2007 & 4382,2 & 24,0 & 426,7 & 265,4 & 322,0 & 463,9 & 5130,9 & 753,3 \\
\hline 2008 & 6892,7 & 30,1 & 644,0 & 531,8 & 275,7 & 715,3 & 7812,3 & 1277,2 \\
\hline 2009 & 7711,8 & 8,5 & 572,9 & 463,3 & 142,1 & 320,6 & 8426,9 & 792,4 \\
\hline 2010 & 7715,8 & 6,0 & 607,9 & 497,2 & 138,5 & 485,8 & 8462,2 & 989,0 \\
\hline 2011 & 10240,1 & 10,7 & 693,8 & 641,5 & 165,6 & 926,2 & 11099,5 & 1578,5 \\
\hline 2012 & 12872,2 & 108,2 & 791,2 & 673,6 & 201,6 & 796,6 & 13865,0 & 1578,5 \\
\hline 2013 & 14903,8 & 185,0 & 755,4 & 596,0 & 156,8 & 924,2 & 15816,0 & 1705,1 \\
\hline 2014 & 14084,4 & 213,3 & 586,2 & 560,4 & 126,0 & 994,5 & 14796,7 & 1768,2 \\
\hline
\end{tabular}

Fonte: Elaboração própria a partir dos dados MDIC/SECEX (2015)

Diante da relevância das exportações no papel de especialização comercial, analisam-se os quatro principais destinos das exportações matogrossenses, entre $2000^{6}$ e 2014 , que, juntos, representaram $52,2 \%$ e $52,8 \%$ do total exportado pelo estado, respectivamente. Em 2000, foram os Países

\footnotetext{
${ }^{6}$ Compara-se o ano de 2000 com 2014, em razão da disponibilidade de dados (SECEX,2015).
} 
Baixos (Holanda) o destino de $32,3 \%$ das vendas do estado, seguido pela Alemanha, Reino Unido e Irã, conforme a Tabela 2.

Tabela 2 - Destino das exportações e sua participação no total exportado por Mato Grosso - 2000 e 2014

\begin{tabular}{|c|c|c|c|c|c|c|c|}
\hline Posição & $\begin{array}{l}\text { Países de } \\
\text { Destino }\end{array}$ & $\begin{array}{c}\text { Exp. em } \\
2014 \\
\text { (Milhões } \\
\text { US\$ FOB) }\end{array}$ & $\begin{array}{c}\text { Part. \% } \\
\text { em } \\
2014\end{array}$ & Posição & $\begin{array}{l}\text { Países de } \\
\text { Destino }\end{array}$ & $\begin{array}{l}\text { Exp. em } \\
2000 \\
\text { (Milhões } \\
\text { US\$ FOB) }\end{array}$ & $\begin{array}{c}\text { Part. \% } \\
\text { em } \\
2000\end{array}$ \\
\hline $1^{\circ}$ & China & 4983,3 & 33,7 & $1^{\circ}$ & $\begin{array}{c}\text { Países Baixos } \\
\text { (Holanda) }\end{array}$ & 333,2 & 32,3 \\
\hline $2^{\circ}$ & $\begin{array}{c}\text { Países Baixos } \\
\text { (Holanda) }\end{array}$ & 1397,6 & 9,5 & $2^{\circ}$ & Alemanha & 80,2 & 7,8 \\
\hline $3^{\circ}$ & Indonésia & 831,8 & 5,6 & $3^{\circ}$ & Reino Unido & 75,3 & 7,3 \\
\hline $4^{\circ}$ & Irã & 595,8 & 4,0 & $4^{\circ}$ & Irã & 50,6 & 4,9 \\
\hline $19^{\circ}$ & Alemanha & 178,1 & 1,2 & $9^{\circ}$ & China & 44,9 & 4,4 \\
\hline \multirow[t]{2}{*}{$18^{\circ}$} & Reino Unido & 189,4 & 1,3 & $<30^{\circ}$ & Indonésia* & $<2,5$ & $<0,2$ \\
\hline & $\begin{array}{l}\text { Demais } \\
\text { Países }\end{array}$ & 6620,9 & 44,7 & & $\begin{array}{l}\text { Demais } \\
\text { Países }\end{array}$ & 449,2 & 43,5 \\
\hline
\end{tabular}

*Dados específicos não disponíveis para menor que a $30^{\circ}$ colocação.

Fonte: Elaboração própria a partir dos dados MDIC/SECEX (2015)

De 2000 a 2014, ocorreram modificações nos cinco principais destinos das exportações mato-grossenses, bem como na intensificação na pauta de exportação. Dos três principais destinos das exportações de Mato Grosso em 2000, têm-se os Países Baixos (Holanda), que, ao longo da década, passaram de $1^{\circ}$ para $2^{\circ}$ no ranking dos destinos das exportações mato-grossenses, caindo de $32,3 \%$ para $9,5 \%$; a Alemanha passou de $2^{\circ}$, com $7,8 \%$, para $19^{\circ}$,

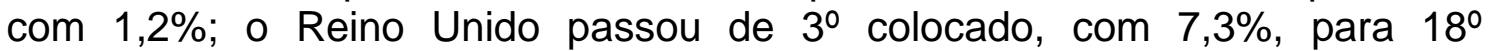
colocado, com $1,3 \%$ e o Irã manteve-se em $4^{\circ}$ colocado, com 4,9\%, e posteriormente, com 4,0\%. Além desses, surgiram a China, que se tornou 0 principal destino, passando de $9^{\circ}$, com $4,4 \%$, para $1^{\circ}$ colocado, com $33,7 \%$, e a Indonésia, que passou para a $3^{\circ}$ colação, com $5,6 \%$.

Em 2014, o cenário apresentou nova configuração em que a China apareceu como maior país importador dos produtos mato-grossenses. De acordo com o Ministério da Agricultura Pecuária e Abastecimento - MAPA (2015), em 2014, as principais exportações mato-grossenses para China pautaram-se em produtos primários, que chegaram a 31,8\% das exportações totais em 2014. Dois produtos que representam quase a totalidade dessas exportações de primários são: a soja e o milho. Segundo Wosch (2002), esse desempenho foi consequência da expansão da demanda, que exerceu influência positiva sobre os preços.

Os cinco setores que apresentaram maior média de participação percentual nas exportações totais de Mato Grosso, de 1999 a 2014, foram alimentos/fumo/bebidas $(89,0)$, madeira $(3,9)$, calçados/couro $(0,9)$, min. n.met/met. preciosos $(0,9)$, têxtil $(5,0)$. No mesmo período, as cinco maiores taxas de crescimento das exportações foram nos setores de material de transporte (80889,9\%); têxtil (30604,0\%); químicos (7313,0\%); min. n.-met/met. preciosos $(3097,6 \%)$; alimentos/fumo/bebidas (1961,4\%). Todavia, os cinco setores que apresentaram menor crescimento foram papel (-92,5\%), ótica/instrumentos, com (-68,9\%), metais comuns, com $(34,6 \%)$; o setor de minerais, com $(60,3 \%)$, e madeira, com $66,2 \%$ conforme a Tabela 3. 
Tabela 3 - Estrutura das exportações mato-grossense segundo grupos de produtos/setores em (\%)

\begin{tabular}{|c|c|c|c|c|c|c|c|c|c|c|c|c|c|c|c|c|c|}
\hline Setores/períodos & 1999 & 2000 & 2001 & 2002 & 2003 & 2004 & 2005 & 2006 & 2007 & 2008 & 2009 & 2010 & 2011 & 2012 & 2013 & 2014 & $\begin{array}{c}\text { Taxa } \\
\text { de cresc. } \\
1999 \text { a } 2014\end{array}$ \\
\hline Alimentos/fumo/bebidas & 89,0 & 89,2 & 88,1 & 89,5 & 86,9 & 84,3 & 87,5 & 88,3 & 86,0 & 89,9 & 91,6 & 90,0 & 89,9 & 89,6 & 92,6 & 91,9 & 1961,4 \\
\hline Minerais & 0,1 & 0,0 & 0,0 & 0,0 & 0,0 & 0,0 & 0,0 & 0,0 & 0,2 & 0,2 & 0,0 & 0,0 & 0,0 & 0,0 & 0,0 & 0,0 & 60,3 \\
\hline Químicos & 0,0 & 0,1 & 0,1 & 0,0 & 0,0 & 0,1 & 0,2 & 0,1 & 0,1 & 0,0 & 0,0 & 0,1 & 0,1 & 0,1 & 0,1 & 0,1 & 7313,0 \\
\hline Plástico/borracha & 0,0 & 0,0 & 0,0 & 0,0 & 0,0 & 0,0 & 0,0 & 0,1 & 0,0 & 0,0 & 0,0 & 0,0 & 0,0 & 0,0 & 0,0 & 0,0 & 1467,7 \\
\hline Calçados/couro & 1,8 & 1,0 & 0,7 & 0,7 & 0,6 & 0,4 & 0,7 & 1,7 & 1,5 & 0,8 & 0,8 & 1,1 & 0,8 & 0,5 & 0,5 & 0,9 & 890,9 \\
\hline Madeira & 7,8 & 7,5 & 6,0 & 5,8 & 6,2 & 6,4 & 4,5 & 4,5 & 4,8 & 2,5 & 1,4 & 1,5 & 1,1 & 0,7 & 0,7 & 0,7 & 66,2 \\
\hline Papel & 0,0 & 0,0 & 0,0 & 0,0 & 0,0 & 0,0 & 0,0 & 0,0 & 0,0 & 0,0 & 0,3 & 0,9 & 0,0 & 0,0 & 0,0 & 0,0 & $-92,5$ \\
\hline Têxtil & 0,3 & 1,5 & 4,7 & 3,3 & 6,0 & 8,6 & 6,9 & 4,3 & 5,7 & 5,5 & 4,3 & 4,8 & 6,6 & 7,9 & 4,2 & 5,2 & 30604,0 \\
\hline Min. N.-met/met. Preciosos & 0,8 & 0,6 & 0,4 & 0,6 & 0,3 & 0,0 & 0,1 & 1,0 & 1,6 & 0,9 & 1,4 & 1,6 & 1,5 & 1,2 & 2,0 & 1,2 & 3097,6 \\
\hline Metais comuns & 0,0 & 0,0 & 0,0 & 0,0 & 0,0 & 0,0 & 0,0 & 0,0 & 0,0 & 0,0 & 0,0 & 0,0 & 0,0 & 0,0 & 0,0 & 0,0 & 34,6 \\
\hline Máquinas/equipamentos & 0,0 & 0,0 & 0,0 & 0,0 & 0,0 & 0,1 & 0,0 & 0,0 & 0,0 & 0,0 & 0,0 & 0,0 & 0,0 & 0,0 & 0,0 & 0,0 & 684,1 \\
\hline Material transporte & 0,0 & 0,0 & 0,0 & 0,0 & 0,0 & 0,0 & 0,0 & 0,0 & 0,0 & 0,0 & 0,0 & 0,0 & 0,0 & 0,0 & 0,0 & 0,0 & 80889,9 \\
\hline Ótica/instrumentos & 0,1 & 0,0 & 0,0 & 0,0 & 0,0 & 0,0 & 0,0 & 0,0 & 0,0 & 0,0 & 0,0 & 0,0 & 0,0 & 0,0 & 0,0 & 0,0 & $-68,9$ \\
\hline Outros & 0,0 & 0,0 & 0,0 & 0,0 & 0,0 & 0,0 & 0,0 & 0,0 & 0,0 & 0,0 & 0,0 & 0,0 & 0,0 & 0,0 & 0,0 & 0,0 & 1037,3 \\
\hline Total & 100,0 & 100,0 & 100,0 & 100,0 & 100,0 & 100,0 & 100,0 & 100,0 & 100,0 & 100,0 & 100,0 & 100,0 & 100,0 & 100,0 & 100,0 & 100,0 & 1896,7 \\
\hline
\end{tabular}

Nota: Os valores em " $0,0 \%$ " apresentam valores maiores que zero a partir da quarta casa decimal.

Fonte: Elaboração própria a partir dos dados MDIC/SECEX (2015). 
Nos primeiros anos da década de 2000, segundo a Empresa Brasileira de Pesquisa Agropecuária - EMBRAPA (2008), o crescimento das vendas externas de Mato Grosso destinadas à China provém da expressiva expansão econômica daquele país. E, em aspectos gerais, pode-se destacar a expansão da demanda mundial de algumas commodities, além do avanço de setores do complexo metal mecânico.

Conforme ressaltado por Lourenço (2011), após o período de instabilidade pós-crise, entre 2007 e 2010, as cotações internacionais das commodities voltaram a ascender, alcançando $26,3 \%$ de variação positiva. Esse movimento ocorreu pela expansão das economias emergentes ocasionadas pelos incentivos monetários e fiscais dos respectivos governos e bancos centrais.

\section{2 Índice de vantagem comparativa revelada simétrica - IVCRS}

A Tabela 4 demonstra a evolução do Índice de Vantagens Comparativas Reveladas Simétricas de Mato Grosso de 1999 a 2014. Dos 14 setores analisados, em apenas um o estado de Mato Grosso apresentou vantagens comparativas (IVCRS $>0$ ) em todos os anos da série histórica, o setor de alimentos/fumo/bebidas. Ou seja, esse setor apresenta especialização permanente em que se refere à competitividade e inserção mato-grossense no mercado internacional. Também apresentaram vantagem comparativa na maior parte do tempo o setor têxtil (2001 a 2014) e o setor de madeira (1999 a 2011). 
Tabela 4 - Índice de Vantagem Comparativa Revelada Simétrica para o Mato Grosso

\begin{tabular}{|c|c|c|c|c|c|c|c|c|c|c|c|c|c|c|c|c|}
\hline Grupos de Produtos\Ano & 1999 & 2000 & 2001 & 2002 & 2003 & 2004 & 2005 & 2006 & 2007 & 2008 & 2009 & 2010 & 2011 & 2012 & 2013 & 2014 \\
\hline Alimentos/fumo/bebidas & 0,50 & 0,58 & 0,51 & 0,51 & 0,49 & 0,49 & 0,53 & 0,53 & 0,51 & 0,50 & 0,44 & 0,48 & 0,48 & 0,45 & 0,44 & 0,43 \\
\hline Minerais & $-0,98$ & $-0,99$ & $-1,00$ & $-1,00$ & $-1,00$ & $-1,00$ & $-1,00$ & $-1,00$ & $-0,98$ & $-0,98$ & $-1,00$ & $-1,00$ & $-1,00$ & $-1,00$ & $-1,00$ & $-1,00$ \\
\hline Químicos & $-0,99$ & $-0,95$ & $-0,97$ & $-0,99$ & $-0,99$ & $-0,94$ & $-0,91$ & $-0,95$ & $-0,95$ & $-0,99$ & $-0,98$ & $-0,95$ & $-0,96$ & $-0,98$ & $-0,97$ & $-0,96$ \\
\hline Plástico/borracha & $-1,00$ & $-1,00$ & $-1,00$ & $-1,00$ & $-1,00$ & $-1,00$ & $-1,00$ & $-0,93$ & $-0,99$ & $-1,00$ & $-1,00$ & $-1,00$ & $-1,00$ & $-1,00$ & $-1,00$ & $-1,00$ \\
\hline Calçados/couro & $-0,42$ & $-0,64$ & $-0,74$ & $-0,72$ & $-0,72$ & $-0,79$ & $-0,62$ & $-0,28$ & $-0,31$ & $-0,43$ & $-0,37$ & $-0,25$ & $-0,30$ & $-0,51$ & $-0,57$ & $-0,38$ \\
\hline Madeira & 0,45 & 0,47 & 0,40 & 0,32 & 0,36 & 0,33 & 0,27 & 0,32 & 0,38 & 0,27 & 0,12 & 0,22 & 0,18 & $-0,05$ & $-0,13$ & $-0,22$ \\
\hline Papel & $-1,00$ & $-1,00$ & $-1,00$ & $-1,00$ & $-1,00$ & $-1,00$ & $-1,00$ & $-1,00$ & $-1,00$ & $-1,00$ & $-0,86$ & $-0,59$ & $-1,00$ & $-1,00$ & $-1,00$ & $-1,00$ \\
\hline Têxtil & $-0,73$ & $-0,22$ & 0,34 & 0,24 & 0,44 & 0,59 & 0,57 & 0,46 & 0,58 & 0,63 & 0,55 & 0,61 & 0,69 & 0,69 & 0,62 & 0,64 \\
\hline Min. N.-met/met. Preciosos & $-0,54$ & $-0,64$ & $-0,72$ & $-0,62$ & $-0,80$ & $-0,97$ & $-0,90$ & $-0,39$ & $-0,13$ & $-0,31$ & $-0,20$ & $-0,12$ & $-0,12$ & $-0,26$ & $-0,05$ & $-0,27$ \\
\hline Metais comuns & $-1,00$ & $-1,00$ & $-1,00$ & $-1,00$ & $-1,00$ & $-0,99$ & $-1,00$ & $-1,00$ & $-1,00$ & $-1,00$ & $-1,00$ & $-1,00$ & $-1,00$ & $-1,00$ & $-1,00$ & $-1,00$ \\
\hline Máquinas/equipamentos & $-1,00$ & $-1,00$ & $-1,00$ & $-1,00$ & $-1,00$ & $-0,99$ & $-1,00$ & $-1,00$ & $-1,00$ & $-1,00$ & $-1,00$ & $-1,00$ & $-0,99$ & $-0,99$ & $-0,99$ & $-1,00$ \\
\hline Material transporte & $-1,00$ & $-1,00$ & $-1,00$ & $-1,00$ & $-1,00$ & $-1,00$ & $-1,00$ & $-1,00$ & $-1,00$ & $-1,00$ & $-1,00$ & $-1,00$ & $-1,00$ & $-1,00$ & $-1,00$ & $-1,00$ \\
\hline Ótica/instrumentos & $-0,99$ & $-1,00$ & $-1,00$ & $-1,00$ & $-1,00$ & $-1,00$ & $-1,00$ & $-1,00$ & $-1,00$ & $-1,00$ & $-1,00$ & $-1,00$ & $-1,00$ & $-1,00$ & $-1,00$ & $-1,00$ \\
\hline Outros & $-0,97$ & $-0,99$ & $-0,98$ & $-0,99$ & $-1,00$ & $-0,99$ & $-0,97$ & $-0,97$ & $-0,94$ & $-0,98$ & $-0,98$ & $-0,98$ & $-0,98$ & $-0,99$ & $-0,99$ & $-0,97$ \\
\hline
\end{tabular}

Fonte: Elaboração própria a partir dos dados MDIC/SECEX (2015) 
Ainda conforme a Tabela 4, os resultados do IVCRS que apresentam maior vantagem comparativa são, em primeiro lugar, os setores de alimentos/fumo/bebidas, com média de 0,49 ao longo do período.

A partir de 2007, as exportações de alimentos, de fumo e de bebidas de Mato Grosso começaram a apresentar pequenas oscilações abaixo da média de 0,49 , principalmente por conta do aumento nos preços das commodities agrícolas, talvez ocasionado pelas incertezas quanto ao comportamento da crise econômica mundial, como o movimento de fechamento de algumas economias que acarretou diminuição das exportações (SECEX, 2015).

Diante destas análises, é possível compreender, sob a ótica das vantagens comparativas, que Mato Grosso possui poucos setores que apresentam vantagens comparativas, ou seja, pauta produtiva com pouca diversificação. Isso pode indicar que o estado é vulnerável às oscilações de variáveis externas (mudança de preços internacionais, crises etc.) e internas (estiagens etc.).

Conforme a Companhia Nacional do Abastecimento - CONAB (2014), em 2013, Mato Grosso foi o principal estado produtor de algodão, milho, soja, carnes com 54,9\%; 23,5\%; 29,0\%; 16,0\% da produção nacional de algodão, respectivamente. Ainda conforme a CONAB (2014), o estado possui grande potencial de expandir a fronteira de possibilidade produtiva, uma vez que há grande extensão territorial fértil inexplorada bem como há maior tendência de crescimento da produção de soja, pois apresenta maior preço e demanda no mercado internacional.

Verifica-se que a segunda maior vantagem comparativa de Mato Grosso ocorre no setor têxtil, com média de 0,42 ao longo do período, com tendência crescente a maior parte do tempo, desde 2001, indicando vantagem comparativa. Ainda não demonstra ter sofrido impactos durante a crise econômica mundial, apenas retrações no ano de 2009 e 2013.

A produção da indústria têxtil aumentou significativamente a partir de 2001, pois, nesse ano, o estado recebeu duas grandes indústrias, a Cottonorth tecelagens e confecções e a Etoile Tecelagem, instaladas no município de Cuiabá. Além disso, o estado estimula atividades industriais em seu território via isenção do Imposto Sobre Mercadoria e Serviços - ICMS (BERCHIELI; FIGUEIREDO; BONJOUR, 2012).

A terceira maior vantagem comparativa do estado é no setor de madeiras, com média de 0,23 ao longo do período, o que indica que Mato Grosso tem se desespecializado nesses produtos, como pode ser verificado pelo resultado decrescente, na maior parte do tempo, ao longo da série histórica, apresentando desvantagem comparativa a partir do ano de 2012.

De acordo com Lima Filho e Timo Ribeiro (2001) e Marta (2007), as serrarias de Mato Grosso apresentam grande dispersão de tamanho, nível tecnológico e o seu processo de agregação de valor é baixo. Esta indústria representa $92 \%$ das empresas do setor da madeira e responde por $59 \%$ da produção física. A fonte de fornecimento desta matéria-prima advém, em partes, de áreas de manejo florestal, mas prevalece, em sua maioria, o fornecimento por áreas desmatadas para exploração de outras atividades como pecuária e agricultura. Neste setor, predomina a cultura nômade, com modelo de gestão familiar, conservador, pouca visão de desenvolvimento e de sustentabilidade do negócio, formada por indústrias de pequeno e médio porte, sem líderes de mercado. 
Entre os principais destinos da madeira serrada estão a Ásia e a Europa. A China (29\%) passou a ser o principal cliente, seguido de França, Espanha e Itália, e a principal madeira exportada é o eucalipto (Instituto Brasileiro de Arvores - IBÁ, 2014).

4.3 Índice de comércio intraindústria - CII

$\mathrm{Na}$ Tabela 5, apresentam-se os resultados do CII, o qual representa o padrão comercial dentro de um mesmo setor. Dos 14 setores analisados, quatro indicaram haver comércio intraindústria em alguns períodos analisados, a saber: minerais (média 0,27) em 1999, 2007, 2008 e 2010; plástico e borracha (média 0,08) em 2006; papel (média 0,20) em 1999 e 2002; outros (média 0,67) em 1999, 2001, 2004 a 2012 e 2014. O resultado para o setor outros é justificado por ser um setor bastante agregado, que contempla os setores armas, munições, móveis, iluminação, brinquedos, produtos de esporte e objetos de arte. 
Tabela 5 - Índice de comércio intraindústria individual para o Mato Grosso

\begin{tabular}{|c|c|c|c|c|c|c|c|c|c|c|c|c|c|c|c|c|}
\hline Grupos de Produtos\Ano & 1999 & 2000 & 2001 & 2002 & 2003 & 2004 & 2005 & 2006 & 2007 & 2008 & 2009 & 2010 & 2011 & 2012 & 2013 & 2014 \\
\hline Alimentos/fumo/bebidas & 0,03 & 0,00 & 0,01 & 0,00 & 0,00 & 0,00 & 0,00 & 0,00 & 0,00 & 0,00 & 0,00 & 0,00 & 0,00 & 0,00 & 0,00 & 0,00 \\
\hline Minerais & 0,87 & 0,33 & 0,06 & 0,01 & 0,01 & 0,02 & 0,02 & 0,04 & 0,62 & 0,74 & 0,39 & 0,78 & 0,40 & 0,01 & 0,02 & 0,01 \\
\hline Químicos & 0,04 & 0,06 & 0,03 & 0,01 & 0,01 & 0,02 & 0,06 & 0,04 & 0,02 & 0,00 & 0,01 & 0,03 & 0,02 & 0,01 & 0,01 & 0,03 \\
\hline Plástico/borracha & 0,04 & 0,01 & 0,03 & 0,25 & 0,01 & 0,00 & 0,00 & 0,66 & 0,17 & 0,01 & 0,01 & 0,00 & 0,00 & 0,02 & 0,02 & 0,04 \\
\hline Calçados/couro & 0,00 & 0,00 & 0,00 & 0,02 & 0,01 & 0,00 & 0,01 & 0,00 & 0,03 & 0,01 & 0,02 & 0,00 & 0,00 & 0,01 & 0,00 & 0,00 \\
\hline Madeira & 0,01 & 0,02 & 0,00 & 0,00 & 0,00 & 0,00 & 0,01 & 0,00 & 0,00 & 0,01 & 0,01 & 0,00 & 0,01 & 0,01 & 0,01 & 0,01 \\
\hline Papel & 0,86 & 0,33 & 0,00 & 0,88 & 0,42 & 0,12 & 0,12 & 0,03 & 0,00 & 0,08 & 0,01 & 0,01 & 0,08 & 0,17 & 0,04 & 0,00 \\
\hline Têxtil & 0,05 & 0,01 & 0,00 & 0,00 & 0,00 & 0,01 & 0,02 & 0,05 & 0,09 & 0,01 & 0,00 & 0,07 & 0,01 & 0,00 & 0,00 & 0,01 \\
\hline Min. N.-met/met. Preciosos & 0,03 & 0,01 & 0,02 & 0,02 & 0,03 & 0,20 & 0,16 & 0,04 & 0,02 & 0,01 & 0,01 & 0,01 & 0,02 & 0,01 & 0,00 & 0,02 \\
\hline Metais comuns & 0,01 & 0,01 & 0,00 & 0,03 & 0,01 & 0,22 & 0,03 & 0,01 & 0,02 & 0,08 & 0,22 & 0,00 & 0,04 & 0,03 & 0,01 & 0,01 \\
\hline Máquinas/equipamentos & 0,03 & 0,02 & 0,00 & 0,03 & 0,02 & 0,31 & 0,05 & 0,03 & 0,05 & 0,03 & 0,02 & 0,06 & 0,11 & 0,05 & 0,12 & 0,03 \\
\hline Material transporte & 0,00 & 0,00 & 0,00 & 0,00 & 0,00 & 0,00 & 0,00 & 0,00 & 0,00 & 0,04 & 0,00 & 0,00 & 0,00 & 0,00 & 0,00 & 0,10 \\
\hline Ótica/instrumentos & 0,01 & 0,03 & 0,00 & 0,06 & 0,00 & 0,10 & 0,01 & 0,00 & 0,01 & 0,00 & 0,03 & 0,00 & 0,00 & 0,00 & 0,01 & 0,00 \\
\hline Outros & 0,90 & 0,43 & 0,62 & 0,28 & 0,02 & 0,51 & 0,84 & 0,88 & 0,69 & 0,94 & 0,88 & 0,88 & 0,83 & 0,70 & 0,50 & 0,89 \\
\hline
\end{tabular}

Fonte: Elaboração própria a partir dos dados MDIC/SECEX (2015) 
Entretanto, para análise dos setores agregados no $\mathrm{Cll}$, os resultados indicaram comércio interindústria para Mato Grosso, que varia em torno de 1\% entre 1999 e 2014. Ou seja, em média, o estado apresenta especialização nos setores com vantagens comparativas como 0 de alimentos/fumo/bebidas; madeira; têxtil, conforme a Tabela 6 .

Tabela 6 - Índice de comércio intraindústria - Cll agregado para o Mato Grosso

\begin{tabular}{cccc}
\hline Ano & CII & Ano & CII \\
\hline 1999 & 0,03 & 2007 & 0,01 \\
2000 & 0,01 & 2008 & 0,01 \\
2001 & 0,01 & 2009 & 0,00 \\
2002 & 0,01 & 2010 & 0,01 \\
2003 & 0,00 & 2011 & 0,00 \\
2004 & 0,01 & 2012 & 0,00 \\
2005 & 0,01 & 2013 & 0,00 \\
2006 & 0,01 & 2014 & 0,00 \\
\hline
\end{tabular}

Fonte: Elaboração própria a partir dos dados MDIC/SECEX (2015)

Entre os setores com maior significância nas exportações estaduais, observa-se que o setor denominado outros (o qual contempla principalmente móveis, iluminação, brinquedos) apresenta alto índice de comércio intraindústria, na maior parte do tempo, indicando forte inserção externa, pois se trata de um setor baseado em expressivas escalas de produção, evidenciando fluxos comerciais de bens do mesmo setor entre Mato Grosso e o resto do mundo. Para Lamas (2007), esse comportamento pode ser explicado não só pela ausência das empresas multinacionais (EMNs) no estado, mas também pelo fato de os setores básicos do estado apresentarem o comércio do tipo tradicional baseado nas vantagens comparativas. Neste caso, apenas exportam produtos desse setor, e, quando importam, os valores são ínfimos se comparados aos valores das exportações.

\section{4 Índice de concentração setorial das exportações - ICS}

A composição da estrutura produtiva de Mato Grosso passou por alterações a partir da segunda metade dos anos 80 e anos 90 (do século XX), as quais foram influenciadas pelo modelo econômico voltado para a produção intensiva, com ênfase na soja (CUNHA, 2011). Adicionam-se a isso as mudanças relacionadas à abertura comercial que se intensificou na primeira metade da década de 1990. Ainda, segundo Diniz (2002), o aumento da competitividade internacional impôs pressão sobre a estrutura produtiva, por um lado, pela presença dos produtos importados no mercado interno e, por outro lado, pela necessidade da produção de produtos competitivos internacionalmente.

Diante desse "novo" quadro, torna-se pertinente verificar o grau de concentração das exportações do estado. A Tabela 7 apresenta 0 grau de concentração das exportações - ICS de Mato Grosso. 
Tabela 7 - Índice de concentração setorial das exportações para Mato Grosso

\begin{tabular}{llll}
\hline Ano & ICS & Ano & ICS \\
\hline 1999 & 0,89 & 2007 & 0,86 \\
2000 & 0,90 & 2008 & 0,90 \\
2001 & 0,88 & 2009 & 0,92 \\
2002 & 0,90 & 2010 & 0,90 \\
2003 & 0,87 & 2011 & 0,90 \\
2004 & 0,85 & 2012 & 0,90 \\
2005 & 0,88 & 2013 & 0,93 \\
2006 & 0,89 & 2014 & 0,92 \\
\hline
\end{tabular}

Fonte: Elaboração própria a partir dos dados MDIC/SECEX (2015)

Como pode ser observado, é possível afirmar que Mato Grosso apresenta uma pauta de exportações concentrada em poucos setores, sendo que a média do indicador (ICS=0,89), no período analisado, é alta, oscilando entre 0,85 e 0,93 . Esse resultado é reflexo das vantagens comparativas do estado, de acordo com os resultados alcançados pelo IVCRS, uma vez que apenas $21,4 \%$ dos setores apresentaram vantagem comparativa (alimentos/fumo/bebidas, madeira, têxtil), bem como o Cll indica que aproximadamente $92,9 \%$ dos setores apresentam comércio baseado em vantagens comparativas, ou seja, interindustrial.

De acordo com a SECEX (2015), ao longo do período, os quatro setores que mais aumentaram as exportações foram máquinas/equipamentos, têxtil, químicos e alimentos/fumo/bebidas. Todavia, os setores que apresentaram as quatro menores taxa de crescimento foram papel, material transporte, metais comuns e minerais.

Segundo os dados da Tabela 3 (a qual considera a análise horizontal), os setores em que mais cresceram as exportações foram aqueles, cujo IVCRS indica vantagem comparativa ou tendência à vantagem comparativa. Isso exceto para o setor de máquinas/equipamentos e químicos, o mais prejudicado dos setores, o que corrobora com a tendência de concentração das exportações do estado de Mato Grosso, também indicada pelo ICS.

\subsection{Taxa de cobertura das importações - TC}

Entre os dois produtos mais relevantes na pauta exportadora matogrossense que apresentaram maiores taxas de cobertura ou maior vantagem comparativa relativa às respectivas importações, ao longo da série, ordenados do maior ao menor, foram os setores de alimentos/fumo/bebidas e calçados/couro. A média deles é de 180,1 e $143,6^{7}$ no intervalo de tempo analisado, respectivamente. Por isso, interpretam-se as variações nos dois principais setores supracitados. Não menos importante, os demais setores que indicaram que as exportações cobrem as importações são madeira, têxtil, min. n.-met/met. preciosos, com média de 57,4; 153,5 e 18,5 em todo o intervalo de tempo analisado, respectivamente, conforme a Tabela 8.

\footnotetext{
${ }^{7}$ Excluso o valor nulo de 2001.
} 
Tabela 8 - Taxa de cobertura do comércio do Mato Grosso - 1999 - 2014

\begin{tabular}{|c|c|c|c|c|c|c|c|c|c|c|c|c|c|c|c|c|}
\hline Grupos de Produtos\Ano & 1999 & 2000 & 2001 & 2002 & 2003 & 2004 & 2005 & 2006 & 2007 & 2008 & 2009 & 2010 & 2011 & 2012 & 2013 & 2014 \\
\hline Alimentos/fumo/bebidas & 13,37 & 47,99 & 30,17 & 51,19 & 57,76 & 123,66 & 141,34 & 108,81 & 186,53 & 244,52 & 190,14 & 179,75 & 281,79 & 239,58 & 442,10 & 543,59 \\
\hline Minerais & 0,15 & 0,02 & 0,00 & 0,00 & 0,00 & 0,00 & 0,00 & 0,00 & 0,07 & 0,10 & 0,02 & 0,18 & 0,04 & 0,00 & 0,00 & 0,00 \\
\hline Químicos & 0,00 & 0,00 & 0,00 & 0,00 & 0,00 & 0,00 & 0,00 & 0,00 & 0,00 & 0,00 & 0,00 & 0,00 & 0,00 & 0,00 & 0,00 & 0,00 \\
\hline Plástico/borracha & 0,00 & 0,00 & 0,00 & 0,02 & 0,00 & 0,00 & 0,00 & 0,05 & 0,01 & 0,00 & 0,00 & 0,00 & 0,00 & 0,00 & 0,00 & 0,00 \\
\hline Calçados/couro & 750,71 & 139,93 & $-*$ & 13,52 & 38,67 & 400,55 & 15,61 & 39,91 & 8,36 & 28,17 & 8,79 & 56,71 & 312,60 & 34,70 & 86,52 & 219,23 \\
\hline Madeira & 39,00 & 11,48 & 68,55 & 69,20 & 181,18 & 98,69 & 38,45 & 65,03 & 79,06 & 33,91 & 30,90 & 54,23 & 48,21 & 27,91 & 30,65 & 41,36 \\
\hline Papel & 0,15 & 0,02 & 0,00 & 0,15 & 0,03 & 0,01 & 0,01 & 0,00 & 0,00 & 0,01 & 18,77 & 17,16 & 0,01 & 0,01 & 0,00 & 0,00 \\
\hline Têxtil & 7,29 & 12,22 & 1153,80 & 139,80 & 93,28 & 23,32 & 9,74 & 3,32 & 3,11 & 42,54 & 160,96 & 3,14 & 26,60 & 164,04 & 93,74 & 39,41 \\
\hline Min. N.-met/met. Preciosos & 15,62 & 25,71 & 8,14 & 13,44 & 7,48 & 1,23 & 1,11 & 5,16 & 18,10 & 48,31 & 36,02 & 18,23 & 16,28 & 16,85 & 50,82 & 13,90 \\
\hline Metais comuns & 0,00 & 0,00 & 0,00 & 0,00 & 0,00 & 0,02 & 0,00 & 0,00 & 0,00 & 0,01 & 0,01 & 0,00 & 0,00 & 0,00 & 0,00 & 0,00 \\
\hline Máquinas/equipamentos & 0,00 & 0,00 & 0,00 & 0,00 & 0,00 & 0,02 & 0,00 & 0,00 & 0,00 & 0,00 & 0,00 & 0,00 & 0,01 & 0,00 & 0,01 & 0,00 \\
\hline Material transporte & 0,00 & 0,00 & 0,00 & 0,00 & 0,00 & 0,00 & 0,00 & 0,00 & 0,00 & 0,00 & 0,00 & 0,00 & 0,00 & 0,00 & 0,00 & 0,01 \\
\hline Ótica/instrumentos & 0,00 & 0,00 & 0,00 & 0,00 & 0,00 & 0,01 & 0,00 & 0,00 & 0,00 & 0,00 & 0,00 & 0,00 & 0,00 & 0,00 & 0,00 & 0,00 \\
\hline Outros & 0,16 & 0,32 & 0,22 & 0,73 & 10,83 & 0,39 & 0,07 & 0,07 & 0,28 & 0,19 & 0,12 & 0,15 & 0,10 & 0,06 & 0,04 & 0,15 \\
\hline
\end{tabular}

*Em 2001 as importações foram nulas, por isso não foi possível calcular o índice.

Fonte: Elaboração própria a partir dos dados MDIC/SECEX (2015) 
O setor de alimentos/fumo/bebidas apresentou trajetória crescente de 1999 a 2005; de 2007 a 2008 e de 2011 a 2014, interrompida nos anos de 2006; 2009; 2010 e 2012. Isso é possivelmente devido à crise econômica mundial, na qual diversos países procuraram diminuir as importações por causa da subida dos preços internacionais dos alimentos. Conforme argumentam Porsse et al. (2009), essas retrações devem-se à desaceleração do crescimento da renda internacional após a crise econômica mundial. Para Figueiredo, Barros, Guilhoto (2005), o valor superior na taxa de cobertura das importações durante toda a série histórica analisada pode estar associado principalmente à produção e à exportação de alimentos e fumo, em razão de a pauta produtiva do estado se concentrar em produtos agrícolas.

A taxa de cobertura para o setor de calçados/couro, ao longo da série, apresenta tendência decrescente ao longo da série, com um comportamento volátil, que registra as principais altas nos anos de 1999, 2004 e 2011; e principais baixas nos anos de 2005, 2007, 2009 e 2012 embora seja possível identificar que as baixas de 2005, 2007 e 2012 estejam associadas ao crescimento das importações maiores que o crescimento das importações. Todavia, em 2009, há maior diminuição das exportações que nas importações. Por isso, acredita-se que o efeito da crise econômica mundial só possa ser verificado no ano de 2009, uma vez que, nos demais anos, se verifica um aumento na demanda interna de Mato Grosso. Porém, uma análise desagregada desse grupo de produtos indica que o resultado positivo da taxa de cobertura deve-se principalmente ao aumento das exportações de insumos da produção de calçados, peles e couro, porque as exportações de calçados apresentam-se nulas na maior parte do tempo. Além disso, percebe-se que as importações de calçados apresentam uma tendência de alta no período analisado, com maiores altas em 2007 e 2009, e maiores baixas em 2004, 2008 e 2012, conforme a Figura 1.

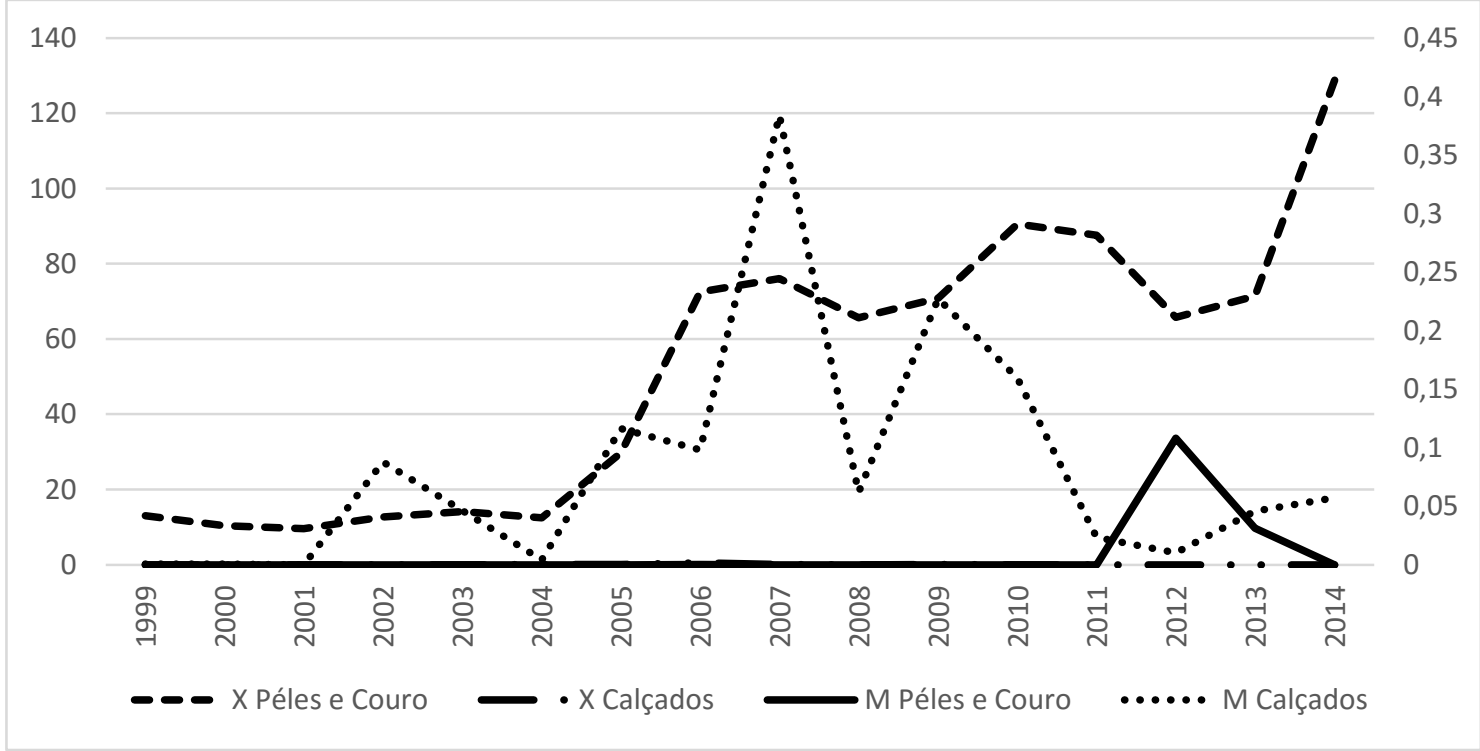

Figura 1 - Evolução das exportações e importações mato-grossenses do complexo calçadista - 1999 - 2014 em milhões de dólares*

Legenda: * $X$ e $M$ referem-se às exportações e importações, respectivamente. Os $X$ e $M$ apresentam resultado relativo ao eixo vertical direito e esquerdo do gráfico, respectivamente. Fonte: Elaboração própria a partir dos dados MDIC/SECEX (2015) 
O principal destino das exportações de insumos da indústria calçadista, peles e couro é a China, a qual também é a principal fornecedora de calçados para Mato Grosso (SECEX, 2015).

\section{CONCLUSÕES}

Este estudo permitiu elucidar o padrão do comércio exterior dos diversos setores do estado de Mato Grosso. A observação conjunta das evidências empíricas apresentadas neste artigo possibilita destacar as peculiaridades setoriais da competitividade do estado no comércio exterior, mostrando que existem três grupos competitivos no mercado internacional: alimentos/fumo/bebidas, têxtil e madeiras.

No início da década de 2000, o grupo calçados/couro apresentou aumento no padrão de especialização de Mato Grosso. Todavia, esse resultado se deu em função do aumento das exportações de insumos da indústria calçadista, ou seja, crescimento da produção e exportação com baixo valor agregado. Ainda na primeira década de 2000, setores como alimentos/fumo/bebidas foram beneficiados pela ascensão da economia chinesa no mercado internacional, a qual demanda produtos básicos e semimanufaturados. Todavia, há grande dependência dos setores ao desempenho da economia chinesa, assim alguma eventual conjuntura na China poderia gerar reduções das exportações mato-grossenses, bem como afetar no padrão de especialização do estado.

Esses indicadores demonstram um padrão de exportação baseado prioritariamente em produtos intensivos em recursos naturais e produtos da indústria de transformação tradicional, caracterizados como manufaturas de baixo valor agregado. Estas são pouco capazes de gerar vantagens comparativas dinâmicas, ou seja, baseadas em inovações tecnológicas, como são encontradas nos padrões internacionais de comércio dos países desenvolvidos. Essa realidade sugere aumento de investimento em tecnologia e inovação, com base nos recursos obtidos do setor primário. Assim, os setores secundário e terciário poderão crescer e se desenvolver.

Considerando a importância do comércio intraindústria, não houve setores que apresentassem padrão consolidado desse tipo de comércio. Como limitações desse indicador, sugere-se que sejam realizados outros trabalhos que desagreguem o setor outros, para verificar se há comércio intraindústria no estado embora, no resultado agregado para o estado, tenha-se verificado que há comércio interindústria. Isto é, Mato Grosso apresenta especialização nos setores com vantagens comparativas.

Em relação aos parceiros comerciais, a China se apresenta como o principal importador, cenário diferente do observado em 1999, em que os Países Baixos (Holanda) eram os maiores compradores de produtos de Mato Grosso. Em relação ao padrão setorial das exportações, observa-se que não houve mudanças, ou seja, a inserção setorial externa restringiu-se à especialização baseada principalmente na dotação de recursos naturais ou básicos. Portanto, os resultados sugerem que as políticas voltadas ao setor exportador devem analisar com melhor acuidade a relação de Mato Grosso com seus tradicionais parceiros comerciais, além de buscar novos parceiros comerciais e ampliar o mix das exportações, mantendo as conquistas obtidas e 
os incentivos ao crescimento e desenvolvimento de produtos manufaturados em busca de diferenciação (maior valor agregado).

Entre as limitações do trabalho está o fato de os índices utilizados serem estáticos, ou seja, permitirem a análise em períodos de tempos específicos, não compreendendo diversas alterações em fatores econômicos como barreiras comerciais, tratados de livre comércio e variações no consumo interno. Por isso, como sugestão, faz-se pertinente a realização de estudos futuros para identificar a possível existência de um processo de desindustrialização no estado de Mato Grosso, bem como trabalhos com a utilização de Modelos de Equilíbrio Geral Dinâmicos, os quais possam mensurar os impactos de políticas econômicas na economia mato-grossense.

\section{REFERÊNCIAS}

APPLEYARD, D.; FIELD JR., A, J.; COBB, S. L. Economia Internacional. 6 ed. Porto Alegre: McGraw Hill, 2010.

AZÚA, D. O neoprotecionismo e o comércio exterior. São Paulo: Aduaneiras, 1986.

BALASSA, B. Trade Liberalisation and "Revealed" Comparative Advantage. The Manchester School, v. 33, n. 2, p. 99-123, maio 1965.

BERCHIELI, R.; FIGUEIREDO, A. M. R ; BONJOUR, S. C. M. . Incentivos fiscais como instrumento da política agrícola recente de Mato Grosso: 19942008. Revista Eletrônica Documento/Monumento, v. 7, p. 68-80, 2012.

BRUM, A. L.; HECK, C. . Economia internacional: uma síntese da análise teórica. ljuí: Unijuí, 2005.

COMPANHIA NACIONAL DO ABASTECIMENTO - CONAB. Conjuntura Agropecuária. Disponível em: /< http://www.conab.gov.br/>. Acesso em: dez. 2014.

CUNHA, J. M. P. da . A dinâmica migratória e o processo de ocupação do Centro-Oeste Brasileiro: o caso de Mato Grosso. Textos NEPO (UNICAMP), v. 60 , p. 1-87, 2011.

DINIZ, C. C. Unidade e fragmentação: a questão regional no Brasil. São Paulo: Perspectiva, 2002.

EMBRAPA. Empresa Brasileira de Pesquisa Agropecuária. Tecnologia de Produção de Soja - Região Central do Brasil, 2008. Disponível em: <http://www.cnpso.embrapa.br/producaosoja/SojanoBrasil.htm>. Acesso em 04 de Out. 2014.

FAJNZYLBER, P.; SARTI, F.; LEAL, J. P. G. Estudo da competitividade da indústria brasileira: sistema de indicadores da competitividade. Campinas: UNICAMP, 1993.

FAUSTINO, H. O Paradoxo de Leontief no quadro das várias teorias do comércio internacional. Estudos de Economia, Lisboa, 1992. 
FEISTEL, P. R. . Modelo Gravitacional: um teste para economia do Rio Grande do Sul. Revista de Economia e Administração, v. 1, p. 94-107, 2008.

FIGUEIREDO, A.; SANTOS, M. Evolução das vantagens comparativas do Brasil no comércio mundial de soja. Revista de Política Agrícola, 2005.

FIGUEIREDO, M. G. ; BARROS, A. M. B. ; GUILHOTO, J. J. M. . Relação Econômica dos Setores Agrícolas do Estado de Mato Grosso com os Demais Setores Pertencentes tanto ao Estado quanto ao Restante do Brasil. Revista de Economia e Sociologia Rural (Impresso), v. 43, p. 557-575, 2005.

FONTENElE, A. M. de C.; MELO, M. C. P.; ROSA, A. L. T. A Indústria Nordestina Sob a Ótica da Competitividade Sistêmica. Fortaleza, EUFC/SUDENE/ACEP, 2000.

GRUBEL, H.; LLOYD, $\mathrm{P}$. Intra-Industry Trade: the theory and the measurement of international trade in differentiated products. London: Macmillan, 1975.

HECKSCHER, E.; OHLIN, B. Heckscher-Ohlin trade theory. [s.I.] The MIT Press., 1991.

HIDALGO, A. B. Especialização e competitividade do Nordeste brasileiro no mercado internacional. Revista Econômica do Nordeste, Fortaleza: BNE, v.29, p. 491-414, jul./set. 1998.

HIDALGO, A. B.; DA MATA, D. F. P. G. Exportações do Estado de Pernambuco: concentração, mudança na estrutura e perspectivas. Revista Econômica do Nordeste, Fortaleza, v. 35, n. 2, abr/jun. 2004.

ILHA, A. S. ; DORNELLES, J. P. ; WEGNER, R. C.. Inserção internacional do Rio Grande do Sul: vantagens comparativas reveladas e comércio intraindústria.. Perspectiva Econômica (Online), v. 5, p. 49-71, 2009.

INDUSTRIA BRASILEIRA DE ÁRVORES (IBÁ). Um mundo de revistas para você. Disponível em: < http://www.bracelpa.org.br/shared/iba_2014_pt.pdf>. Acesso em: fev. 2015.

INSTITUTO DE PESQUISA EM ECONOMIA APLICADA (IPEA). IPEADATA: Banco de Dados do Instituto de Pesquisa em Economia Aplicada. Macroeconômico. 2012. Disponível em: <http://www.ipeadata.gov.br/>. Acesso em: jan. 2014.

KRUGMAN, P. R.; OBSTFELD, M. Economia internacional: teoria e política. 8 ed. São Paulo: Pearson Addison Wesley, 2010.

LAMAS, E. Quadro Geral do Comércio Exterior do RS. Indicadores Econômicos FEE, v. 35, p. 61-75, 2007.

LAURSEN, K. Revealad comparative advantage and the alternatives as Measures of International specialization. Working Paper, n. 98-30, Copenhagen: Danish Rearch Unit for Dynamics, 1998. 
LIMA FILHO, D. O. TIMO RIBEIRO, C. V. O Agronegócio da Madeira: a estrutura competitiva da Indústria de Serraria de Mato Grosso. I Jornada Científica do Centro-Oeste de Economia e Administração - UFMS, 2001. Disponível em: <http://www.ufms.br/dea/oficial/JORNADA\%20PDF/2001/artigos/12.pdf>. Acesso em: 01 set. 2009.

LINDER, S. An essay on trade and transformation. Stockholm: Almqvist \& Wiksell, 1961.

LOURENÇO, G. M. A superinflação das commodities. Análise Conjuntural. Curitiba: IPARDES, v.33, n.5-6, maio/jun. 2011.

MAIA, J. Economia Internacional e Comércio Exterior. [s.I]: Editora Atlas, 2006.

MAIA, S. F. Transformações na estrutura produtiva do estado do Paraná na década de 90: análise por vantagem comparativa. In: Sinézio Fernandes Maia; Natalino Henrique de Medeiros (Org.). Transformações Recentes da Economia Paranaense. Recife: Editora Universitária, 2005, v. 1, p. 65-88.

MARTA, J. M. A indústria madeireira em Mato Grosso - um processo de formação. In: XLV Congresso Sober, 22 a 25 de jul. 2007. UEL, Londrina - PR.

MINISTÉRIO DO DESENVOLIMENTO DA INDÚSTRIA E COMERCIO EXTERIOR (MIDIC). Secretaria de Comércio Exterior (SECEX). Disponível em: <http://aliceweb2.mdic.gov.br//consulta-ncm/index/type/exportacaoNcm >. Acesso em: 31 de janeiro de 2015.

PINHERES, G. S.; FERRANTINO M.: Export diversification and structural dynamics in the growth process: the case of Chile, Journal of Development Economics, vol. 52, No. 2, Amsterdam, Elsevier Science, abr. 1997.

PORSSE, A. A.; PALERMO, P. U. ; STAMPE, M. Z.; PEIXOTO, F. C. . Aplicação de um modelo insumo-produto econométrico para análise dos impactos da crise na economia gaúcha. In: XII Encontro de Economia da Região Sul, 2009, Maringá. XII Encontro de Economia da Região Sul, 2009.

PORTER, M. A vantagem competitiva das nações. 15. ed. Rio de Janeiro: Elsevier Editora Ltda, 1989.

RICARDO, D. Principles of Political Economy and Taxation. [s.I.] P. Sraffa and M. Dobb, 1817.

SALVATORE, D. Economia internacional. 6a. Edição. Rio de Janeiro: LTC, 2000.

SANTOS, R. S. . Fronteira Agrícola, Força de Trabalho e o Processo de Urbanização. Caminhos de Geografia (UFU), v. 13, p. 264-279, 2012.

SMITH, A. A riqueza das nações: uma investigação sobre a natureza e as causas da riqueza das nações. São Paulo: Madras, 2009. 
VIANNA, S. T. W.; BRUNO, M. A. P.; MODENESI, A. M. Macroeconomia para - Desenvolvimento: crescimento, estabilidade e emprego. 4. ed. Rio de Janeiro: IPEA, 2010.

WILLIAMSON, J.; MILNER, C.; WHEATSHEAF, H. The world economy: a textbook in international economics. [s.l: s.n.]. 1991.

WOSCH, L.F.O. Dinâmica dos Mercados no Fluxo de Comércio do Paraná com o Exterior. In: Análise Conjuntural, v.24, jul/ago. 2002. 